\title{
An Institutional Perspective on the Conflict between Teaching and Research in Chinese Local Universities
}

\author{
Wanxian Li \\ School of Public Administration \\ Hebei University of Economics and Business \\ Shijiazhuang, China \\ Email: lwx2011@126.com
}

\author{
Jinguo Ye \\ Center of Synergy Creation on Law and Morality \\ Hebei University of Economics and Business \\ Shijiazhuang, China \\ Yejinguo218@163.com
}

\begin{abstract}
Literature review on the institutional transition of Chinese higher education indicates that the fundamental reason for current conflict between teaching and research in local universities rooted mainly from the traditional educational resource allocation and evaluation system as well as the state central power traditions generated in the elite education era. The institutional reformation falls behind the current society development requirements of higher education popularization. Therefore, the institutional countermeasures could be: Setting up Diversified Fund and multivariate evaluation System as well as empowerment to universities for state education policy makers while reforming faculty management and students training systems for the universities. This conclusion suggests that Chinese higher education requires further reformation on the institutional level rather than that on the university management level as of the past theory and practice indicated so as to copy with the higher education popularization era.
\end{abstract}

Keywords-institution conflict teaching and research Chinese local universities elite education higher education popularization

\section{INTRODUCTION}

Since higher education reformation in 1999, most universities in China, especially the local or provincial universities has changed their mission from elite education to popular education and undergone continuous expansion till today. However, due to the impediment of the traditional institutional environment the universities made no progress in practicing their new mission even with the ever growing numbers of students and at a result suffering the conflicts between teaching and research either in theory or practice.

Chinese universities can be categorized into three types: Research universities, teaching and research universities and teaching universities. ${ }^{[1]}$ Research universities (RU) cover $5 \%$ of Chinese universities, which focus on elite education, training postgraduates of doctors or masters. The teaching and research universities (TRU) , covering 65\% of Chinese universities, aim at advanced specialists education, functioning as both elite education training postgraduates and public higher education training undergraduates. On one hand, TRU undertake important responsibilities in local scientific and technological achievements transformation, on the other hand, they have to perform the duty of teaching around 20 thousand students, among which two thirds are undergraduates. Around $30 \%$ of Chinese universities are Teaching Universities (TU) or local higher education institutions belonging to public higher education those mainly training practical technical specialists, normally with less or no research requirements and objectives. It can be seen that the above three higher educations have different objectives and tasks. However, under the same databased evaluation system ( both national and social evaluation), all universities have to pay attention to both teaching and research, even TRUs and TUs have to follow RUs on research achievements in order to obtain the national funds and social reputation. Due to the internal conflicts between research and teaching, the Chinese Local Universities are suffering the most sever conflict between teaching and research.

\section{CONFLICTS BETWEEN TEACHING AND RESEARCH}

There has been a long debate worldwide about the relationship between teaching and research in higher learning. About the internal conflict between teaching and research, Barnett (1992:623) stated "knowledge in the context of discovery and knowledge in the context of transmission are entirely different enterprises". He explained the dichotomy in terms of six theses: (1) Research is public; higher education is private. (2) Research is a matter of outcome; higher education is a matter of process. (3) In higher education, learning is intended; in research, it is a by-product. (4) Higher education is open: research is closed. (5) Research is a necessary but not a sufficient ingredient for higher education. (6) The academic community is directly related to research but indirectly related to higher education. [2] Therefore, higher education is universally considered as teaching-oriented while research as a by-product in local universities undertaking a large number of undergraduates education, especially in current era of higher education popularization.

However, in reality, due to the long-term effect and difficult quantification of teaching, while relatively more convenience of research assessment, the evaluation institutions prefer to use more of research statistics rather than teaching standards or levels as the criterion for university evaluation. With such data-based evaluation system, it is difficult for universities to balance the relationship between teaching and research. On the one hand, teaching is the duty and 
responsibility of the university and it has no reason to overlook the teaching quality and the students learning, while on the other hand the university has to pay more attention to research in order to get the national or organizational funds and better social reputation for its existence under current competition environment of higher education.

The conflict also happens on the departmental level. The teaching department holds the idea that teaching is the main function of the university and emphasizes the teaching centered commission: teaching is the nature of the teachers' job, and learning is the nature for students, while research is after all a by-product of the university which should not rob the place of the host. However, the research department insists that it is researching that can promote the university rankings, raise the reputation and lift up the social positions of the university. Therefore, the university has to incline to scientific research rather than teaching.

For the university faculties, they are also facing such dilemma toward how to balance the teaching and research conflicts. Spending less time on teaching the teacher may feel a loss of conscience toward students, while without or less research achievements directly leads to his both material and spiritual loss of self. Therefore, to meet the requirement of the data-based evaluation, the faculties have to suffer the mentally conflicts to try to find time conducting research. What's more, research seems more attractive than teaching for it is not only funded by the government, or quasi-governmental agencies, but also organized on a customer-contract basis (Barnett (1992:622). Just as Leslie Stephen (2001) stated “To be a good teacher one must be a good researcher. Hence appointment, promotion, tenure, and salary are based entirely on status in research.”, ${ }^{[3]}$

\section{INSTITUTIONAL ANALYSIS ON TEACHING AND RESEARCH CONFLICTS}

The relationship between teaching and research has been a worldwide issue that could not be uniformed till today. Davies and Glaister (1995:281) stated when analyzing UK university mission statements, that this analysis "...is fraught with difficulties, not least in identifying suitable criteria and minimizing subjectivity." ...About sixty-one per cent of the mission statements (forty-two in total) gave approximately equal weighting to teaching and research, with a greater teaching emphasis in about thirty-two per cent of the mission statements (twenty-two in total) with most of these mission statements coming from the "new" universities. Only about three percent of the mission statements emphasized research more than teaching (two in total) these being mission statements from the old universities. ${ }^{[4]}$

In spite of the internal conflicts between teaching and research, some institutional factors could also be decisive reasons for the conflict. First of all is Financial allocation system and the university evaluation system. Universities in China were traditionally funded by the government and the state financial allocation has been the main educational resource for the universities. The scarcity of educational appropriation determines that the state financial allocation cannot meet the needs of all universities. Therefore, Chinese government started the new financial allocation system of average cost of a student plus special funds since 90 s of 20 century. For the former, all the universities are equally funded, but for the latter, only those with key laboratories, project research centers and subjects can obtain the fund, which means scientific research become the evaluation criterion, and this baton of research leads the universities blind comparison leaving aside their own commission of teaching and unilaterally emphasizing scientific research. ${ }^{[5]}$ This researchbased evaluation system are also copied by the nongovernmental evaluation organizations in university rankings. Therefore, the local universities have to follow the national research universities and focus on research achievements rather than teaching quality in order to get the government fund and better social reputation.

The second institutional reason for the teaching and research conflict could be the government's over control of the universities. The national education council as well as the provincial education department not only control education resources, but also handle some management affairs such as the university evaluation, the university administrators' appointment and the teachers' promotion etc. There could be two disadvantages of this management system. One is that the more power it holds, the busier it is and the worse effect of management, especially in the era of Small government and big society. The other disadvantage is that the administrators in the government normally are non-professionals in either teaching or research. Therefore, it cannot be expected to have any ideal management effect in any of teaching and research affairs. What's more, the government's over control of education affairs leads directly to the loss of the university autonomy in their mission making and development strategy planning as well as their administrative implementations all in a dilemma in whether focusing on teaching or research.

Apart from the external institutional factors, the misplacement of the university orientation could be the other important cause for the teaching and research conflict. Before higher education reformation, most Chinese universities, including local ones are elite education. From the beginning of 21 century, Chinese higher education, especially the local universities has changed from elite education into popular education, and yet the external traditional evaluation system remains the same. Therefore, the education differentiation could not be identified and implemented by local universities and as a result, most of them still copy the few research universities in an attempt to crowd into the first-class universities by raising their research achievements. A universal proof can be seen in the university faculty promotion that besides a certain amount of teaching work requirements, research achievements, the number of key-journal published papers become the decisive element in promotion.

Following the university utility orientation, The value bias occurs both in departmental level and individual level that emphasize research while neglect teaching, and this biased value directly leads to over utilitarian academic purpose and the over quantification of research achievements. In most Chinese universities, research has become (an accepted due custom) No. one matter to pursuing the research GDP in order to gain the statistical amount of achievement. ${ }^{[6]}$ This biased value not only directly influences teaching in different degrees, 
but also triggers the falsification behavior on academic paper writing and publishing and at a result, the numbers of research achievements rapidly rises while the research quality falls. What's worse is that the academic corruption overturns the traditional social reputation of higher education.

\section{INSTITUTIONAL SOLUTIONS TOWARD THE CONFLICT BETWEEN TEACHING AND RESEARCH}

The institutional inertia and institutional logic could be the fundamental reason for the displaced relationship between teaching and research. Therefore, to balance the relationship between teaching and research we need institutional reformation. As the different level institution makers, the government and the university should set up the right idea of diversification in the era of higher education popularization in institution choice and arrangements, and carry it out into the institutional decisions and implementations.

\section{A. Setting up Diversified Fund System in Higher Education.}

The fundamental reason for local or non-research universities focusing more on research than teaching is that they wish to obtain educational resources. Therefore, the government should adjust the education funds and set up diversified fund system of higher learning, adopting different funding system toward research university and non-research university, and increase total fund to the non-research universities in order to encourage them focusing more on teaching rather than research, while at the same time make use of the incentives of the economic lever, inspecting and evaluating the teaching quality of non-research universities by connecting the amount of funding with the teaching quality.

\section{B. Building multivariate evaluation system of higher education.}

The evaluation to the university has double functions; it is the assessment to the university working achievement, and also the direction to the university future development. Therefore, it is important for the government to set up the evaluation system associating with popular education development, adopting related evaluation indexes toward different types of universities an different higher education evaluation. For research universities, enhance scientific indexes while focus more on teaching indexes toward nonresearch universities. What's more, the government should also guide the social evaluations with its media superiority, regulating the social value of higher education in the era of higher education popularization.

\section{Devolve management power to universities.}

The New Public Administration Movement in the past decades indicates that the government role is steering rather than paddling. The government supervision and administration toward higher education institutions should be macroscopic but not microcosmic. It ought to devolve its power, especially the micro management power down to universities so as to concentrate on the macro affairs such as the higher education strategic planning, the reasonable allocation of education resources and the macro university inspection etc. This is not only necessary for government empowerment, but also is a must in the era of higher education popularization. On the one hand, it is impossible for the a few education administrators to deal with so many specific educational affairs of about two thousand universities in the whole country. On the other hand, the government administrators can not handle some specific affairs fairly and effectively as the laymen in both teaching and research. Therefore, the government education department should empower some micro affairs, for instance, the teaching and research evaluation and the teachers promotion etc., to the universities or related social organizations, this is not only a good encouragement for universities autonomy but also release the education administrators to focus on some more important educational issues.

\section{Reforming the faculty management and students training system.}

The university function of teaching and research is revealed by the faculty community. Thus, the university, as the subject of its internal institution maker, must change the current unitary faculty management system, placing research post and separating out those with higher research abilities and aspiration in scientific research, while making reasonable rules for those interested in both teaching and research and encourage them to do some research on improving their teaching so as to realize the regurgitation-feeding function of research toward teaching and finally reach the harmonious relation between teaching and research. ${ }^{[7]}$

It is obvious from stated above that the conflicts between teaching and research for Chinese local universities fundamentally rooted from the government funding and evaluating system as well as central power customs. Therefore, it is badly needed that the government institutional reformation, especially in higher education: Not only change the research-oriented funding and evaluating system into diversified fund and evaluating system, but also require an ideological change from the traditional centralization custom into decentralization ideology, devolving management power to universities, which could be a double benefit of both releasing the government from too much specific affairs and liberating the universities from their tension of conflicts between teaching and research, and what's more important is that the university could be able to implement their initial missions. In one word, Chinese higher education requires further reformation on the institutional level rather than that on the university management level in order to copy with the higher education popularization era.

\section{REFERENCES}

[1] Qiuying Han, “ Study on the relationship between teaching and research in the teaching-research universities. Modern Education Science, 2012, (1),pp. 118-121. (In Chinese)

[2] Barnett, R. "Linking Teaching and Research: A Critical Inquiry", Journal of Higher Education, Vol.63, No.6, 1992, pp.619-636.

[3] Leslie Stephen, Chapter 4: Case Studies and Conflict Resolution, 2001 Jack S. Levy. In: The SAGE Handbook of Conflict Resolution.Edited by: Jacob Bercovitch, Victor Kremenyuk \& I William Zartman.DOI: http://dx.doi.org/10.4135/9780857024701.n5

[4] Davies, S.W. and Glaister, K.W. "Spurs to Higher Things? Mission Statements of UK Universities”, Higher Education Quarterly, Vol.50, No.4, 1996, pp.261-294.

[5] Fei He, On the Ethos of Local Universities. PhD dissertation, Huazhong University of Science and Technology, Wuhan, China. April, 2005,pp: 6. 
Indexed by CNKI, http://kns.cnki.net/kns/brief/default_result.aspx. (In Chinese)

[6] Xu Chaofu \& Su Huiwen, Confusion and Solution: the Relationship between Teaching and Research, FORUM ON CONTEMPORARY EDUCATION, 2015(1),pp:1-10. (In Chinese)

[7] Ze Li and Rujun Cao, An inspection toward the relationship between teaching and research in the era of higher education popularization, Journal of Higher Education, Mar., 2008 Vol.29 No.3.pp: 51-56. (In Chinese) 